\title{
THE ROLE OF STUDENTS IN THE PANDEMIC ERA COVID-19 IN REALIZING THEIR STUDENTS IN THE VILLAGE OF SOREANG
}

\author{
Kuswanto $^{1}$, Hana Yunansah ${ }^{2}$, \\ 1,2 Universitas Pendidikan Indonesia, Kampus Cibiru, Bandung, Indonesia \\ ${ }^{1}$ kuswanto.8@upi.edu, ${ }^{2}$ hanayunansah@upi.edu
}

\begin{abstract}
The Covid-19 pandemic has greatly affected all social structures of life, from denominations, socio-culture, tourism and even education. In this condition, almost all activities are carried out from home, including school from home, where at the tertiary level there is one course that must be done directly in the community, namely KKN. Then the solution is online KKN. The program implemented is data collection on various matters related to Covid-19 and education on the prevention of Covid-19. The approach is carried out through social media, namely Whatsapp to the local government to collect data and social media Facebook or Youtube for the publication of activities for making Covid-19 prevention media in the form of posters, infographics and videos. Involving several partners, namely Madrasah Teachers for the socialization of PPE in the form of masks and MTs Teachers for making learning videos. Another program is the creation of an application containing Covid-19 explanations for elementary school students named CO.AP (Covid Application).
\end{abstract}

Keywords: Pandemic Covid-19 2, Technology 3, Independent study

\section{A. Introduction}

Real Work Lecture $(\mathrm{KKN})$ has been established since 1973 by DITJEN DIKTI as a form of community service by university students. $\mathrm{KKN}$ is also a part of curricular activities for undergraduate students at a certain level and within a predetermined period of time. In 1985, KKN was designated as an intracurricular activity with an academic load of 3-4 credits (Soeteja, 2020 pp. 1)

Real work lectures are an obligation that must be done by every student because it is included in a course so that every year it will always be carried out. Especially in 2020, unexpected things happened, which greatly changed various social structures of life, including the education sector. There was a Covid19 pandemic which is a disease caused by the Novel Corona Virus (2019$\mathrm{nCoV})$, a new type of coronavirus that in humans causes serious diseases such as Middle East Respiratory Syndrome (MERS) and Severe Acute Respiratory Syndrome (SARS) (Pikobar, 2020). 
The National Disaster Management Agency (BNPB) has designated Covid19 as a national disaster. This statement was stated in the Presidential Decree (Keppres) of the Republic of Indonesia Number 12 of 2020 concerning the Determination of Non-Natural Disasters for the Spread of 2019 CORONA VIRUS DISEASE (COVID-19) as a National Disaster. The Presidential Decree contains 3 other points, namely the determination of disaster management by the Task Force for Handling Corona Virus Disease 2019 (COVID-19) according to Presidential Decree No.7 of 2020 as amended into Presidential Decree No.9 of 2020 into the Task Force for the Acceleration of Handling of Corona Virus Disease 2019 (COVID-19) through synergy between ministries/agencies and local governments. Orders to the governors, regents and mayors as the Chairperson of the Regional Task Force for the Acceleration of Handling Corona Virus Disease 2019 (COVID-19), in determining their policies, they must pay attention to central policies. The last point is that the determination of the policy will take effect from Monday 13 April 2020 (Gusty, 2020).

The spread of Covid-19 according to WHO is through droplets or vomit (fomites) in unprotected contact and through objects that come into contact with patients such as bathroom door handles, toilet seats and sinks. So that prevention that must be done is to wash hands, cover mouth and nose when coughing and get used to keeping a distance from other people of about one meter (Wijoyo dan Indrawan, 2020). Therefore, people are encouraged to carry out social distancing and physical distancing so that transmission can be prevented but in the end it has an impact on the issuance of a policy to carry out all activities from home including work and school activities. Including lecture activities, one of which is KKN. Then the Community Service Program is carried out online. This is in line with the policy published through BNPB that Social and Physical Distancing must involve figures up to RT/RW.

Online KKN is something very new and is one of the first to be done. There are many pros and cons that occur but 
must be carried out considering that this activity cannot be postponed and must comply with government regulations, so this online $\mathrm{KKN}$ is the solution. Absolutely there are advantages and disadvantages in its implementation, including students not being able to meet directly and experience when working face-to-face with the community. However, there are also many advantages, namely that the university can still work together with the community even though online, students can be closer to the community where they live and experience more use of technology because they are required to master various digital things such as making posters, videos and the use of social media.

\section{B. Method of Implementation}

Covid-19 Thematic KKN to Realize Freedom of Learning (Covid-19 MMB Thematic KKN). with the theme of Covid-19 Prevention Education. The implementation of this KKN activity was carried out in Soreang Village RT 03 RW 03 Soreang District, Bandung Regency on May 17, 2020 to June 17, 2020 by involving several parties including the Chairman of RW 03 Soreang namely Mr. Andi Supriono, Chairman of RT 03 Soreang namely Mr. Diki Rusaman and Ibu Kader RW 03 Soreang, this involvement is for the purposes of community data collection. Then for the distribution or socialization of masks, the Al-Munawwar madrasa teacher, Mrs. Atin Hayati (Umi), was involved and for the strengthening of learning, the teacher of MTs Nurul Falah, Ms. Wina Nur Qomariyati, was involved. The status of the program taken is non-volunteer with the Field Advisory Lecturer, $\mathrm{Mr}$. Kuswanto, M.Pd..

The KKN program flow is Student Education and Training, implementation of $\mathrm{KKN}$, guidance by DPL, monitoring and evaluation and final reporting. The program targets are students of Elementary School (SD), Junior High School (SMP) and the community in Soreang Village RT 03 RW 03 Soreang District, Bandung Regency. The programs and activities carried out are data collection of the population according to age, level of education, occupation, etc., data collection of 
residents who enter the RT, RW where students live, data collection of residents who leave the RT, RW where students live, data collection of community conditions that show symptoms Covid19, data collection on positive community conditions for Covid-19, data collection on the condition of the community that shows symptoms of Covid-19, data collection on the economic conditions of people who work/do not work, data collection on the economic conditions of traders/entrepreneurs/drivers/laborers/ etc. and collecting data on the economically disadvantaged population. Another program is the making and socialization of PPE in the form of masks and a covid prevention education program for elementary, junior high school students and the surrounding community through posters, learning videos, videos about filling spare time when Covid-19 and making applications about Covid-19. With additional programs, namely data collection on toddlers in RW 03 Soreang and data collection on residents with an age range of $0-5,6-10,11-15,16-20$, and so on.
The KKN approach is carried out individually in the student residence. The strategy is carried out by using Whatsapp social media to contact the local government and contact other partners such as Ibu Kader, Madrasah Teachers and MTs Teachers; Facebook to publish the results of making posters and infographics; Youtube to publish the results of video creation and Zoom to conduct training and guidance. Making media uses the Canva, PPT, kinemaster, powtoon and unity applications.

\section{Result and Discussion}

The activity that was carried out for approximately 30 days resulted in several findings based on data collected through interviews on Whatsapp with the local government and calculations based on the KK given:

1. There are $275 \mathrm{KK}$, with the following details, RT $01=51 \mathrm{KK}$, RT $02=16 \mathrm{KK}, \mathrm{RT} 03=40 \mathrm{KK}$, RT $04=97 \mathrm{KK}, \mathrm{RT} 05=71 \mathrm{KK}$.

2. The number of residents is 914 people, with 474 men and 440 women 
3. The largest number of residents aged 5-9 years, 35-39 years and 10-14 years

4. The minimum number of residents is 70-74 years old, 65-69 years old and 0-4 years old

5. The highest levels of education are high school graduates and the least are tertiary graduates

6. There were 3 people who entered the RW 03 Soreang area who carried out independent isolation for 14 days

7. There were 3 people who left the RW 03 Soreang area on the grounds that they moved house and returned to their hometown.

8. RW 03 Soreang Village is a green zone

9. No residents experienced Covid-19 symptoms, were positive for Covid19 and died from Covid-19.

10. There are 37 people affected by Covid-19, 30 people have been given assistance and 7 people have not received assistance

11. A total of 12 residents are still working due to economic needs and are dominated by casual daily laborers and 4 residents do not work because they are affected by Covid19

12. The total number of children under five (0-5 years) in RW 03 Soreang is 53 with 28 boys and 25 girls.

Other programs include the Covid-19 prevention education program for elementary, junior high school students and the surrounding community in the form of posters "Tips for Protecting the Body during the Pandemic and Fasting Month", infographics "How to Care for Children during the Covid-19 Outbreak", posters "Towards the New Normal", posters "Don’t be Lezy when Corona", posters "Applications about Covid-19 (1) and (2)", posters "New Symptoms of Covid-19 (1), (2), (3), (4), (5) and (6)". Learning videos "Triangles and Squares" and videos to fill spare time during Covid-19 "Rubik Snake Tutorial (ball)". The Covid-19 prevention application is called CO.AP (Covid Application). Finally, the making and socialization of PPE in the form of masks for elementary students. 
Poster and Infographic Creation

Pict. 1

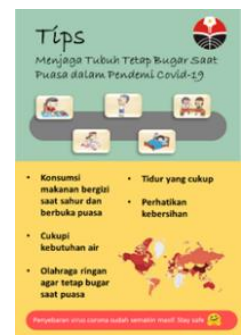

Pict. 4
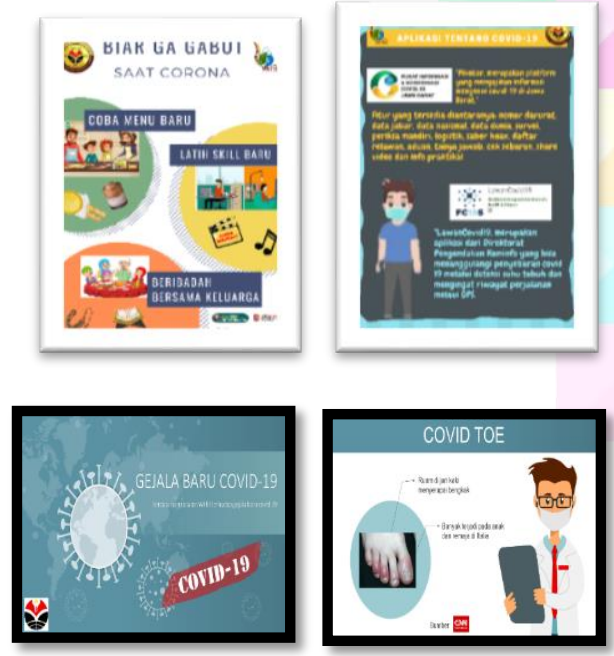

Pict. 5

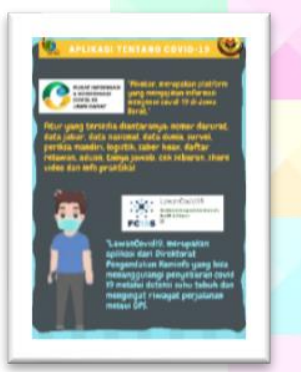

Pict. 6

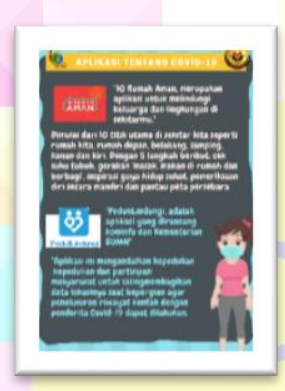

Pict 3
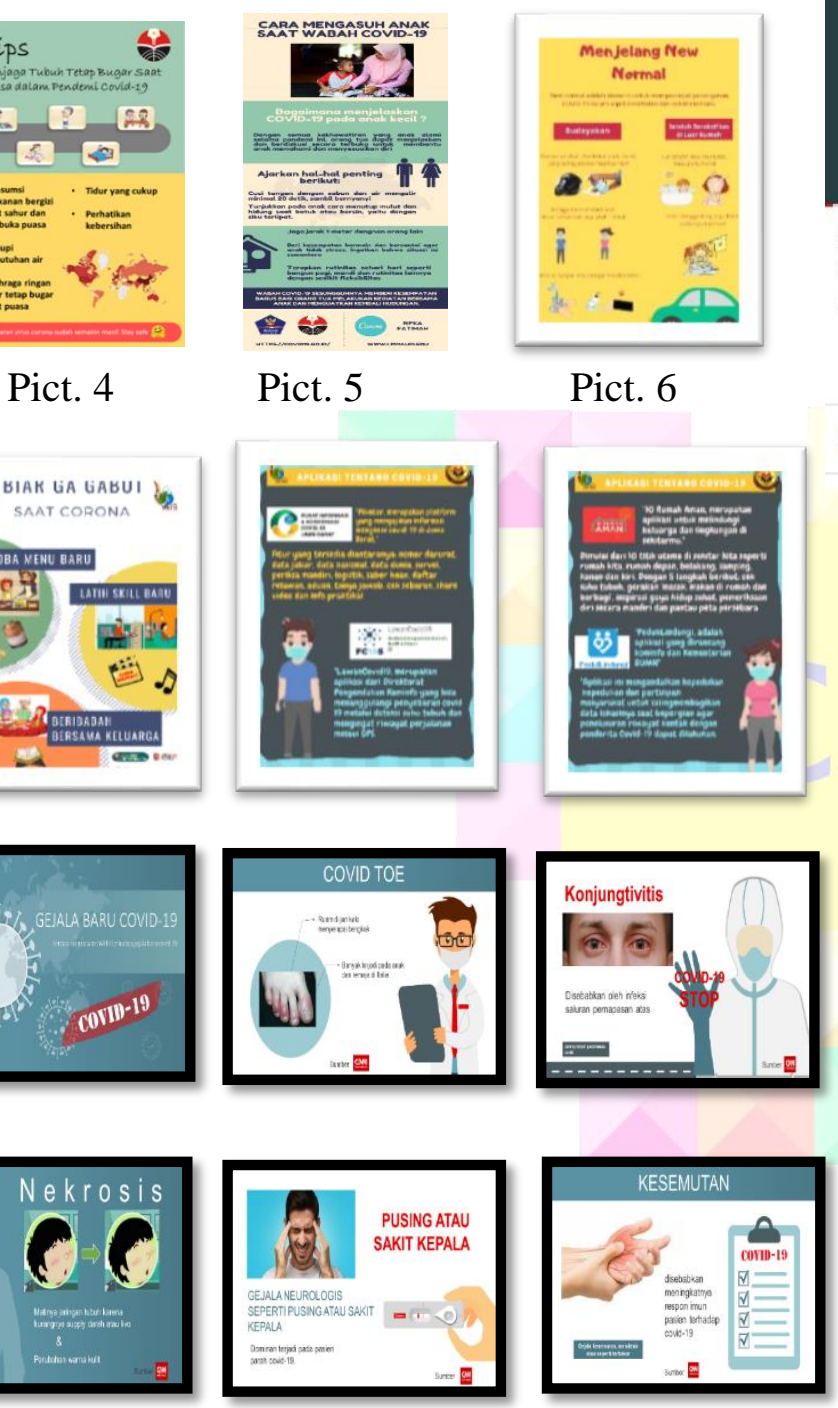

Pict. 13

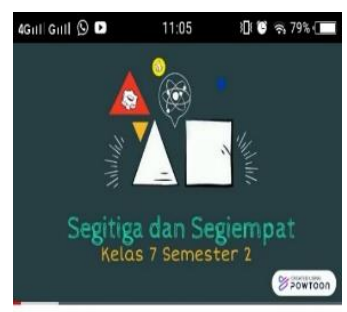

Segitiga dan Segiempat (Kelas 7 Semester 2)

$10 \times$ ditionton

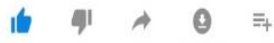

1. Bagkan Download Simpan

R Rifka Fatimah

Tidak ada subscriber

SUBSCRIBE

Trakada subscriber

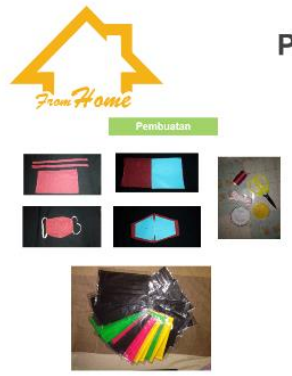

Pembuatan dan Sosialisasi APD

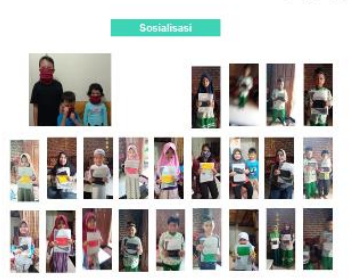

Pict. 7 until 12 Learning Videos, Covid Applications and APD Socialization

\section{Conclusion}

KKN activities in the village itself make students closer to the community around their residence as well as a means of self-actualization in activities that exist in the community, especially the data 
collection program because it is very necessary. The response from the government and local residents was very positive. Even though all programs are run online, they can still run well thanks to strong intentions and assistance from related partners.

The results of the general data collection show that of the 914 residents in RW 03, Soreang Village, none of them showed symptoms of Covid-19, were positive for Covid-19 or died due to Covid19. For residents who enter the area during the pandemic, they are self-isolating for 14 days. There are several residents who have been affected by covid-19, some have been given assistance by the government, but some have not. Some residents still work because of urgent economic needs, among those who are still working are casual daily laborers.

\section{REFERENCES}

BNPB. (2020).

https://setkab.go.id/kebijakansocial-dan-physical-distancingharus-libatkan-tokoh-sampai-rt- rw/. (Artikel). Diakses pada 30 Juni 2020.

Gusty, S., Nurmiati., Muliana., dkk. (2020) Belajar Mandiri: Pembelajaran Daring di tengah Pandemi Covid-19. Medan: Yayasan kita menulis.

Pikobar.

(2020) https://pikobar.jabarprov.go.id/

Soeteja, Zakaria S. (2000). http://jurnal.upi.edu/file/Zakarias .pdf. (Jurnal). Diakses pada 29 Juni 2020.

Suryaningprang, Andre, Lella NQ Irwan, and Mujibah A. Sufyani. "INCREASING WOMEN'S PARTICIPATION IN EDUCATION IMPROVING SKILLS THROUGH ONLINE MEDIA AND BUSINESS INTRODUCTION TO SMES FOR MEMBERS OF THE PKK IN THE VILLAGE CIWALENSUKARESMI DISTRICT OF CIANJUR REGENCY, WEST JAVA PROVINCE." PICS-J: Pasundan International Community Services Journal 1.1 (2019): 18-27.

Wijoyo, dan Indrawan, I. (2020). Model Pembelajaran Menyongsong New Era Normal pada Lembaga PAUD di Riau. Jurnal Unimed: JS (Jurnal Sekolah) 4 (3), 205212, 2020. 